\title{
The relationship between quality protein, lean mass, and bone health
}

\author{
Jeremy P Loenneke ${ }^{1 *}$, Abhishek Balapur ${ }^{1}$, Austin D Thrower ${ }^{1}$, Georganne Syler ${ }^{2}$, Maureen Timlin², Thomas J Pujol ${ }^{1}$ \\ From International Society of Sports Nutrition: 7th Annual ISSN Conference and Expo \\ Clearwater Beach, FL, USA. 24-26 June 2010
}

\section{Background}

The amount of quality protein (Essential Amino Acids (EAA): Protein) intake, and distribution of that protein to a meal, could play an important role with regard to lean mass (LM), bone mineral density (BMD), and bone mineral content (BMC). Research has demonstrated that muscle protein synthesis (MPS) is maximally stimulated at $\sim 10 \mathrm{~g}$ of EAA per meal (Cuthbertson, et al. 2005). A cross sectional study sought to determine the relationship between the amount of quality protein consumed in 24 hours and the amount of times the $\sim 10 \mathrm{~g}$ EAA threshold was reached at a meal, with respect to $\mathrm{LM}, \mathrm{BMD}$, and BMC.

\section{Methods}

Twenty-seven healthy males and females $(22.0 \pm 3.19$ yrs; $169.68 \pm 8.20 \mathrm{~cm} ; 71.72 \pm 13.95 \mathrm{~kg}$ ) participated in this study. EAA intake was determined from a 3-day food record, and amino acid profiling for each food was determined using a computer program (Nutrition Data). $\mathrm{LM}, \mathrm{BMD}$, and BMC were measured using dual-energy $\mathrm{X}$-ray absorptiometry (DEXA). Quality protein was defined as the ratio of EAA to total dietary protein. Data were analyzed using Pearson partial coefficient correlations, controlling for body mass, with an alpha level of 0.05 .

\section{Results}

Quality protein consumed in a 24 hour period was positively associated with $\mathrm{LM}(\mathrm{r}=.585, \mathrm{p}=.002)$, BMD $(\mathrm{r}=.607, \mathrm{p}=.001)$, BMC $(\mathrm{r}=.557, \mathrm{p}=.003)$, and had an inverse relationship with body fat percentage (BF\%) $(\mathrm{r}=-.574, \mathrm{p}=.002)$. Reaching the EAA threshold for a

\footnotetext{
${ }^{1}$ Department of Health, Human Performance, and Recreation, Bone Density Laboratory, Southeast Missouri State University, Cape Girardeau, MO 63701, USA

Full list of author information is available at the end of the article
}

meal, multiple times per day, was also positively associated with LM $(\mathrm{r}=.677, \mathrm{p}=.001), \mathrm{BMD}(\mathrm{r}=.539, \mathrm{p}=$ $.004), \mathrm{BMC}(\mathrm{r}=.435, \mathrm{p}=.02)$, and like the 24 hour quality protein intake, had an inverse relationship with BF\% $(\mathrm{r}=-.664, \mathrm{p}=.001)$.

\section{Conclusion}

It is concluded that quality protein intake, including the frequency by which the EAA threshold $(\sim 10 \mathrm{~g})$ is reached for a meal, is positively associated with favorable body composition and bone health.

\section{Author details}

'Department of Health, Human Performance, and Recreation, Bone Density Laboratory, Southeast Missouri State University, Cape Girardeau, MO 63701, USA. ${ }^{2}$ Department of Human Environmental Studies. Southeast Missouri State University, Cape Girardeau, MO 63701, USA.

Published: 15 September 2010

\section{doi:10.1186/1550-2783-7-S1-P1}

Cite this article as: Loenneke et al.: The relationship between quality protein, lean mass, and bone health. Journal of the International Society of Sports Nutrition 2010 7(Suppl 1):P1.

\section{Submit your next manuscript to BioMed Central} and take full advantage of:

- Convenient online submission

- Thorough peer review

- No space constraints or color figure charges

- Immediate publication on acceptance

- Inclusion in PubMed, CAS, Scopus and Google Scholar

- Research which is freely available for redistribution 